\title{
Fagopyritol, a Derivative of D-chiro-inositol, Induces GLUT4 Translocation via Actin Filament Remodeling in L6-GLUT4myc Skeletal Muscle Cells
}

\author{
Hajin Nam', In Koo Hwang ${ }^{2}$, Harry Jung ${ }^{3}$, Seung-Hae Kwon ${ }^{4}$, Ok Kyu Park ${ }^{4}$ and Jun Gyo Suh ${ }^{1,3_{\star}}$ \\ ${ }^{1}$ Institute of Natural Medicine, Hallym University, Chuncheon, Gangwon 200-702, Korea \\ ${ }^{2}$ Department of Anatony and Cell Biology, College of Veterinary Medicine, and Research Institute for Veterinary Science, Seoul National University, \\ Seoul 151-742, Korea \\ ${ }^{3}$ Department of Medical Genetics, College of Medicine, Hallym University, Chuncheon, Gangwon 200-702, Korea \\ ${ }^{4}$ Korea Basic Science Institute Chuncheon Center, Chuncheon, Gangwon 200-701, Korea
}

Received August 7, 2013 /Revised August 31, 2013 / Accepted September 24, 2013

\begin{abstract}
Insulin induces glucose transporter 4 (GLUT4) translocation to the muscle cell surface. As fagopyritol has insulin-like effects, the effects of fagopyritol on GLUT4 translocation and filamentous (F) actin remodeling in L6-GLUT4myc skeletal muscle cells were investigated. Fagopyritol significantly increased plasma membrane GLUT4 levels compared with the basal control in L6-GLUT4myc myoblast cells. Phosphatidylinositol (PI) 3-kinase inhibitor (LY294002) treatment prevented GLUT4 translocation to the plasma membrane in the myoblasts. Fagopyritol treatment apparently stimulates F-actin remodeling in myoblasts. In addition, fagopyritol treatment induced GLUT4 translocation and F-actin remodeling in myotubes. Taken together, these results suggest that fagopyritol promotes GLUT4 translocation and F-actin remodeling by activating the PI 3-kinase-dependent signaling pathway.
\end{abstract}

Key words : Fagopyritol, Glucose transporter 4 (GLUT4) translocation, Actin filament, D-chiro-inositol, L6-GLUT4myc myoblasts

\section{Introduction}

Insulin-stimulated glucose transporters (GLUTs) play an important role in the regulation of blood glucose levels [3]. Insulin quickly increases the rate of glucose uptake into the primary glucose-consuming tissues, such as skeletal muscle and adipose tissue, in which glucose transporter 4 (GLUT4) is specifically expressed at a significant level $[9,10]$. GLUT4 is mainly localized in the intracellular storage pool and translocates to the plasma membrane in response to insulin [22]. This phenomenon is defective in insulin resistance and type 2 diabetes (T2DM) [12]. In T2DM, a defect that is associated with impaired GLUT4 translocation, fat cells and muscle fibers appear to be insensitive to the hormone [31]. The process by which GLUT4 triggers an increase in glucose uptake is a complex signaling cascade, which is still not fully understood.

\footnotetext{
*Corresponding author

Tel : +82-33-248-2692, Fax : +82-33-248-2690

E-mail : jgsuh@hallym.ac.kr

This is an Open-Access article distributed under the terms of the Creative Commons Attribution Non-Commercial License (http://creativecommons.org/licenses/by-nc/3.0) which permits unrestricted non-commercial use, distribution, and reproduction in any medium, provided the original work is properly cited
}

In addition, Insulin-dependent GLUT4 translocation requires dynamic remodeling of filamentous (F) actin [2]. In several events, such as vesicle trafficking, the F-actin cytoskeleton plays a major role in insulin-regulated GLUT4 vesicle dynamics [23]. It is well known that insulin causes a rapid and marked remodeling of actin filaments below the plasma membrane, promoting membrane ruffling in cells such as myotubes, adipocytes, and fibroblasts [27]. Disruption of the actin cytoskeleton prevents the arrival of GLUT4 at the cell surface of muscle and adipose cells [6, 31].

Endogenous GLUT4 is not expressed until it is differentiated into myotubes [16]. L6 myoblasts respond poorly to insulin. A myc epitope-tagged GLUT4 (GLUT4myc) into L6 myoblasts is reported to markedly improve insulin sensitivity and responsiveness of glucose uptake in L6 myoblasts [29]. The level of expression of GLUT4myc in myoblasts was similar to the endogenous level of GLUT4 in myotubes [29]. Thus, the myc epitope-tagged GLUT4 (GLUT4myc) into L6 myoblasts was used in this study.

Buckwheat (Fagopyrum esculentum Moench) has quite a few beneficial bioactive components such as D-chiro-inositol (DCI), flavonoids, and sterols [7, 34]. Fagopyritols are derivatives of the D-chiro-inositol (DCI) that accumulates in the seeds of common buckwheat. Fagopyritols have been isolated from not only buckwheat seeds but also soybean, lu- 
pine, lentil, chickpea, sugar beet, mung bean, and jojoba [4, 13]. $\mathrm{DCI}$ is a component of galactosamine $\mathrm{DCI}$, a putative insulin mediator, known to be deficient in T2DM patients [8]. DCI and its galactosides (fagopyritols) have been reported to lower blood glucose levels [13].

We have previously reported that fagopyritol promotes glucose uptake in L6 myoblast cells [24]. But that mechanism by which this is accomplished is not yet clearly understood. In this study, the effect of fagopyritol on GLUT4 tanslocation and actin filament remodeling in L6-GLUT4myc rat myoblast cells was investigated.

\section{Materials and Methods}

\section{Materials}

Fetal bovine serum (FBS), a-MEM, and other cell culture reagents were purchased from GIBCO (Burlington, Ontario, Canada). Monoclonal anti-myc (9E10) antibody was purchased from Santa Cruz Biotechnology Inc. (Santa Cruz, CA, USA). Cyanine 3-conjugated goat anti-mouse (Cy3-conjugated goat anti-mouse) and Cyanine 5-conjugated goat anti-mouse (Cy5-conjugated goat anti-mouse) antibodies were purchased from Jackson Immunoresearch Laboratories Inc. (West Grove, PA, USA). Rhodamin-phalloidin (R-415) was purchased from Invitrogen (Carlsbad, CA, USA). Insulin and LY294002 as phosphatidylinositol 3 kinase (PI3K) inhibitors were purchased from Sigma-Aldrich (St. Louis, MO, USA).

\section{Preparation of the fagopyritol}

Fagopyritol was supplied by S\&D Co. (Chuncheon, South Korea) used in vitro culture after radio-sterilization. This fagopyritol was extracted from the skin of buckwheat by $50 \%$ ethanol at $80^{\circ} \mathrm{C}$ and used in vitro culture after radiosterilization. The fagopyritol used in this experiment contained over $9.57 \%$ DCI.

\section{Cell culture, differentiation, and treatment}

L6 rat myoblasts normally expressing GLUT4 with an exofacial myc epitope (L6-GLUT4myc cells) (kind gift from Amira Klip, the Hospital for Sick Children Toronto, ON, Canada) were cultured according to the following protocols [29]. L6 myoblast cells were grown in a-MEM supplemented with $10 \% \mathrm{FBS}$ and $1 \%$ penicillin/streptomycin $(100 \mathrm{U} / \mathrm{ml}$ penicillin and 100 microgram $/ \mathrm{ml}$ streptomycin) in 5\% humidified air at $37^{\circ} \mathrm{C}$. L6 myoblasts were differentiated into myotubes in a-MEM supplemented with $2 \%$ FBS, $1 \%$ pen- icillin/streptomycin, and 1\% Fungizone. Before any trials were conducted, the cells were incubated in serum-free aMEM for $4 \mathrm{hr}$. Cell viability was not compromised under any of these conditions (data not shown). The treatment dose (1 mM) was chosen according to the results obtained in dose-response and time-course assays [24].

\section{Trafficking of GULT4myc translocation}

The cells were placed in a $3 \mathrm{~cm}$ confocal dish with cover slip and then incubated in a a-MEM buffer for $30 \mathrm{~min}$ at $37^{\circ} \mathrm{C}$ and then incubated in insulin for $10 \mathrm{~min}$. After fixation with $2 \%$ para-formaldehyde for $10 \mathrm{~min}$ at room temperature (RT), the cells were washed with phosphate buffered saline (PBS), and incubated in $0.1 \mathrm{M}$ glycine in PBS for $15 \mathrm{~min}$ at RT. The cells were incubated with PBS containing 10\% goat serum for $30 \mathrm{~min}$ at $4^{\circ} \mathrm{C}$. Primary antibody (anti-c-myc, 9E10; Santa Cruz Inc., Santa Cruz, CA, USA) was diluted to 1:50 ratio and incubated for $1 \mathrm{hr}$ at $4^{\circ} \mathrm{C}$. The cells were extensively washed with cold PBS. The secondary antibody (Cy3-anti-mouse, Jackson Immunoresearch., West Grove, PA, USA) was diluted to 1:500 ratio and incubated for $1 \mathrm{hr}$ at $4^{\circ} \mathrm{C}$. After washing with PBS, the cells were mounted with a mounting medium with DAPI (H-1200, Vector Laboratories. Inc., Burlingame, CA, USA). Immediately, fluorescent images were captured immediately using a confocal imaging system (LSM-510 META NLO, Carl Zeiss, Randburg, Germany). All digital images were captured at the same settings in order to allow direct quantitative comparison of staining patterns. The fluorescent intensity of red GLUT4 translocation was measured by Image J software [5]. Fluorescence intensities of GLUT4myc were normalized by subtracting background intensities.

\section{Filamentous actin staining}

To stain actin filaments, the cells were incubated in $2 \mathrm{ml}$ KRH buffer for $30 \mathrm{~min}$ at $37^{\circ} \mathrm{C}$ and then incubated in 300 $\mathrm{nM}$ insulin. After fixation with 3\% para-formaldehyde (20 $\mathrm{min}, \mathrm{RT})$, the cells were incubated for neutralization in 0.1 $\mathrm{M}$ glycine in PBS for $10 \mathrm{~min}$ at $4^{\circ} \mathrm{C}$. Then, Rhodamin phalloidin (R415, Invitrogen, Carlsbad, CA, USA) was added at 1 unit per dish for $1 \mathrm{hr}$ at RT. After washing with PBS, the cells were mounted with a mounting medium with DAPI (H-1200, Vector Laboratories. Inc.). Fluorescent images were captured Immediately using a confocal imaging system (LSM-510 META NLO, Carl Zeiss). 


\section{Quantification and statistical analysis}

Several representative images of GLUT4myc translocation from three separate trials were quantified with the use of Image J software ( $\geq 30$ cells per condition). The data are presented as the mean \pm SEM. To determine statistical significance, the data were analyzed using student's $t$ test. A value of $p<0.05$ was considered to be statistically significant.

\section{Results}

Fagopyritol stimulates the translocation of GLUT4
to the plasma membrane in L6-GLUT4myc myoblast
cells

This study shows the morphological changes and immunoreactivities on GLUT4 translocation and filamentous (F) actin remodeling in L6-GLUT4myc myoblasts and myotubes treated with a $1 \mathrm{mM}$ concentration of fagopyritol. Fagopyritol treatments stimulated GLUT4 translocation and filamentous (F) actin remodeling of L6-GLUT4myc myoblasts and myotubes. In a previous study, fagopyritol promoted glucose uptake in L6 myoblast cells [24]. The present study, thus, investigated whether fagopyritol can induce GLUT4 translocation, causing increased glucose uptake in L6-GLUT4myc myoblasts. Fagopyritol significantly increased plasma membrane GLUT4 levels compared with the basal control condition, $p<0.05$ (Fig. $1 \mathrm{~A}$ and 1B). L6GLUT4myc myoblasts were treated with LY294002, insulin, or fagopyritol for $20 \mathrm{~min}$. This treatment prevented the insulin-stimulated association of GLUT4myc with insulin or fagopyritol (Fig. 1A-d, f, and 1B).

Fagopyritol stimulates filamentous actin remodeling in L6-GLUT4myc myoblast cells

To examine whether the cell surface was remodeled, rhodamine-phalloidin was used to stain F-actin. In the basal state, stress fiber was evenly distributed across the myoblast surface (Fig. 2a, d, and g; white arrows). Upon insulin or fagopyritol stimulation, a correspondence in the actin aggregates was observed (Fig. 2b, c, e, f, h, and i; white triangles).

Fagopyritol induces GLUT4 translocation and filamentous actin remodeling in L6-GLUT4myc myotubes

The myoblasts differentiate spontaneously after confluency into multinucleated myotubes when cultured in low concentrations of serum [15]. The multiple myonuclei were confirmed by DAPI staining (blue) (Fig. $3 \mathrm{~d}$, e, and f). The cells were fixed and double-stained for $\mathrm{F}$ actin (green, rhodamine-phalloidin) and GLUT4myc (red, an anti-myc antibody followed by a Cy5-conjugated secondary antibody). Upon insulin or fagopyritol stimulation, a marked correspondence was observed in the actin aggregates on the plasma membrane of cells (Fig. 3a, b, c, j, k, and l; white triangles). Also, fagopyritol apparently increased plasma membrane GLUT4 levels compared with the basal control condition in myotubes (Fig. 3g, h, and i). In both myoblasts and myotubes, fagopyritol stimulated GLUT4 translocation and $\mathrm{F}$ actin remodeling. In both myoblasts and myotubes, fagopyritol stimulated GLUT4 translocation and F actin remodeling.

\section{Discussion}

In this study, we have shown the morphological changes and immunoreactivities on GLUT4 translocation and filamentous (F) actin remodeling in L6-GLUT4myc myoblasts and myotubes treated with a $1 \mathrm{mM}$ concentration of fagopyritol. It was found that this remodeling was positively stimulated by fagopyritol treatment.

Fagopyritols are derivatives of DCI. Body stores, mainly in muscle and urine, of DCI gradually decrease in patients with diabetes (both type 1 and type 2) and obesity [19]. This symptom may be in part due to increased urinary losses through an unknown mechanism of DCI [33]. DCI, an inositol derivative, has been shown to act as an anti-diabetic compound by improving insulin sensitivity in patients exhibiting insulin resistance due to diabetes or polycystic ovary syndrome $[1,25]$.

Insulin caused a twofold increase in cell surface content in GLUT4myc and in glucose transport activity in L6-GLUT4myc myoblasts [24]. Thus, in L6 myoblasts, ectopic expression of GLUT4 generated an insulin-responsive phenotype [32]. GLUT4 translocation to the plasma membrane is mostly regulated by two distinct signaling pathways, the PI3K/Akt- and AMP-activated protein kinase (AMPK)-dependent signaling pathways [17]. As PI3K is required for insulin-mediated recruitment of GLUT4 [26], the interaction of GLUT4myc with fagopyritol was examined in the presence of the PI3K inhibitor LY294002. LY294002 treatment prevented insulin or fagopyritol from stimulating GLUT4myc translocation. This result indicates that fagopyritol, in part, promotes GLUT4 translocation by activating the 
A

Control
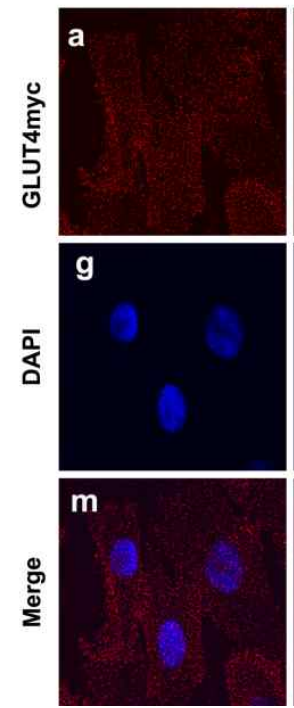

Control+LY
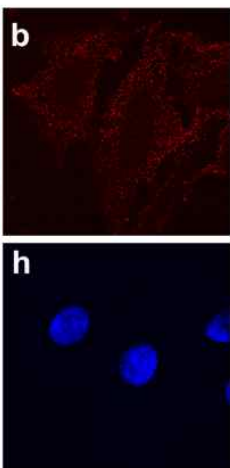

n

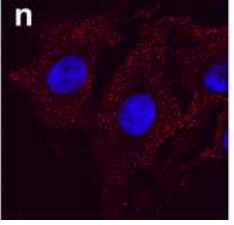

Insulin
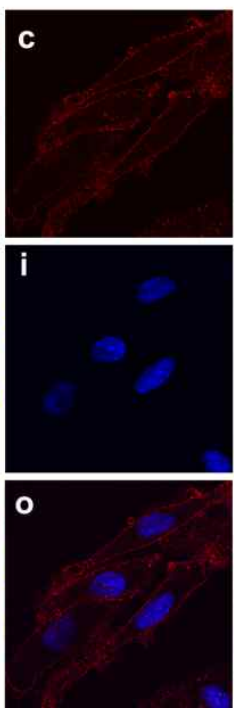

Insulin+LY
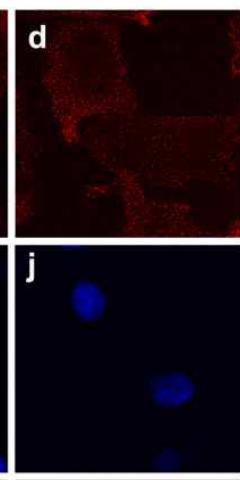

p

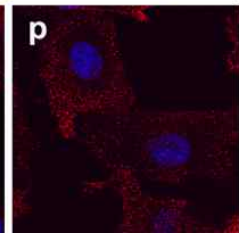

Fagopyritol
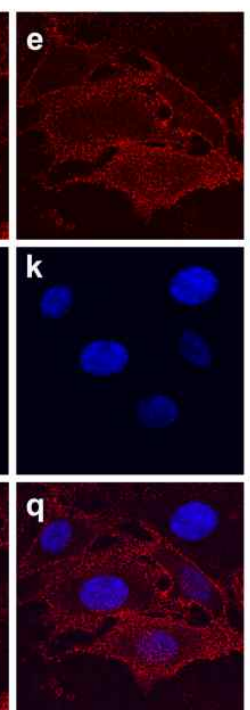

Fagopyritol+LY
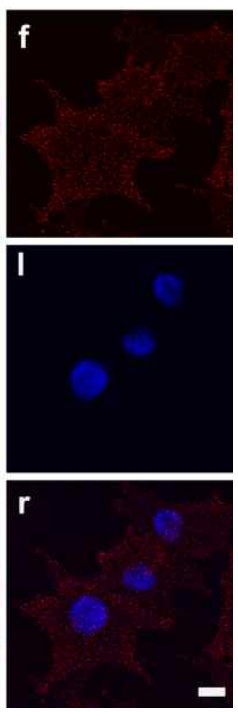

B

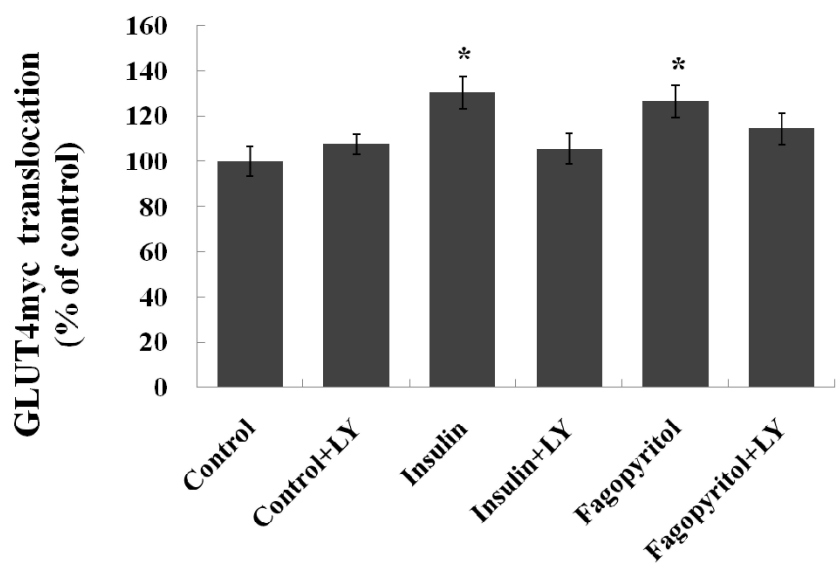

Fig. 1. Fagopyritol treatment induces GLUT4 translocation. LY294002 as PI3 kinase inhibitor treatment prevents GLUT4 translocation. (A) Immunostaining of GLUT4 in non-permeabilized L6-GLUT4myc cells. Intact L6-GLUT4myc cells were stained with anti-myc mouse IgG (9E10), and subsequently with Cy3 goat anti-mouse IgG to detect surface GLUT4myc (red). The myonuclei were identified by DAPI staining (Blue). Insulin $(100 \mathrm{nM})$, fagopyritol $(1 \mathrm{mM})$, and LY294002 $(0.01 \mathrm{mM})$ were treated for $10 \mathrm{~min}$. Representative immunofluorescence images of 3 independent experiments. Scale bar, $10 \mu \mathrm{m}$. (B) Quantification of cell surface GLUT4myc content. Data are means \pm SEM and expressed relative to the values in basal control cells. ${ }^{*} p$ value $<0.05$ as compared to the basal control.

PI3K-dependent signaling pathway.

It was found that insulin-stimulated F-actin membrane ruffles in L6 myoblasts accumulated at localized plasma membrane sites and directed the localization of both PI3 kinase and GLUT4 protein [30]. Insulin also stimulation induced a rapid reorganization of actin filaments into a cortical mesh in muscle cells. Some studies have shown that actin remodeling is required for GLUT4 translocation and glucose uptake into cells either by connecting signaling or by making the tracks on which GLUT4 vesicles can move in myocytes [14, $20,28]$ and adipocytes $[11,18]$. It has been reported that dis- ruption of the actin cytoskeleton prevents the arrival of GLUT4 at the cell surface of muscle and adipose cells [21, 27].

Yap et al. have also reported that DCI, L-chiro-inositol (LCI), epi-inositol, muco-inositol, and D-pinitol induced GLUT4 translocation in the L6 myotubes and skeletal muscles of rats ex vivo [35]. This result suggests that fagopyritol stimulates GLUT4 translocation via actin filament remodeling.

In conclusion, our current findings provide strong evidence to support the hypothesis that fagopyritol improves 


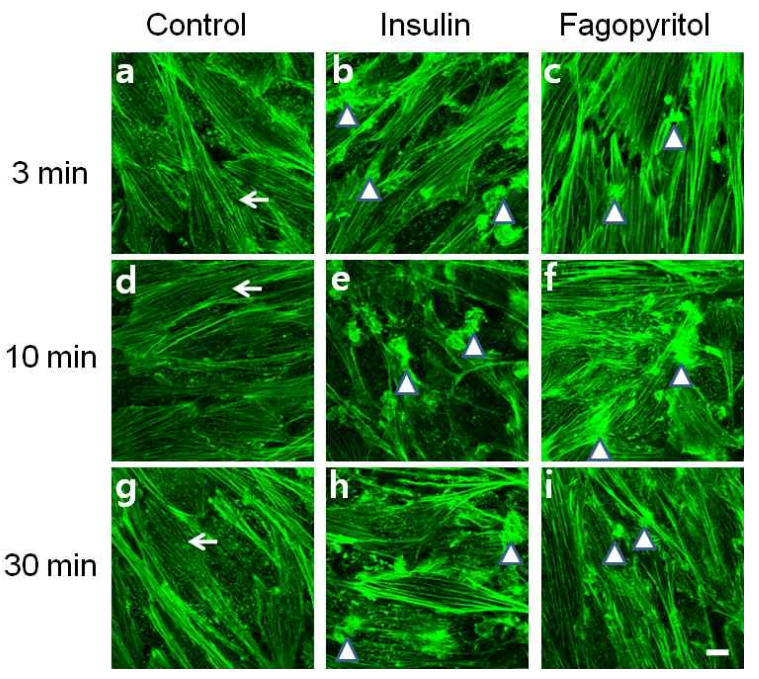

Fig. 2. Fagopyritol treatment induces $\mathrm{F}$ actin remodeling in L6-GLUT4myc myoblast cells. Serum-deprived L6GLUT4myc myoblast cells were treated with $100 \mathrm{nM}$ insulin or $1 \mathrm{mM}$ fagopyritol for 3, 10, and $30 \mathrm{~min}$ at $37^{\circ} \mathrm{C}$. Afterward, the cells were fixed, permeabilized, and stained for F-actin (green, rhodamine-phalloidin). White arrows indicate stress fiber $(\mathrm{a}, \mathrm{d}$, and g). White triangles indicate the $\mathrm{F}$ actin aggregates caused by remodeled actin filaments (b, c, e, f, h, and i). Scale bar, $10 \mu \mathrm{m}$. The images are representative of three experiments.

glucose uptake mainly by promoting GLUT4 translocation and F-actin remodeling in skeletal muscle. Therefore, the consumption of fagopyritol might ameliorate the symptoms of diabetes mellitus and polycystic ovary syndrome.

\section{Acknowledgement}

This work was supported by Priority Research Centers Program through the National Research Foundation of Korea (NRF) funded by the Ministry of Education, Science and Technology (NRF-2009-0094071).

\section{References}

1. Al-Nozha, O., Habib, F., Mojaddidi, M. and El-Bab, M. F. 2013. Body weight reduction and metformin: Roles in polycystic ovary syndrome. Pathophysiology 20, 131-137.

2. Bai, L., Wang, Y., Fan, J., Chen, Y., Ji, W., Qu, A., Xu, P., James, D. E. and $\mathrm{Xu}, \mathrm{T}$. 2007. Dissecting multiple steps of GLUT4 trafficking and identifying the sites of insulin action. Cell Metab 5, 47-57.

3. Chung, M. J., Lee, Y. S., Kim, B. C., Lee, S. B., Moon, T. H., Lee, S. J. and Park, K. H. 2006. The hypoglycemic effects of acarviosine-glucose modulate hepatic and intestinal glucose transporters in vivo. Food Sci Biotechnol 15, 851-855.

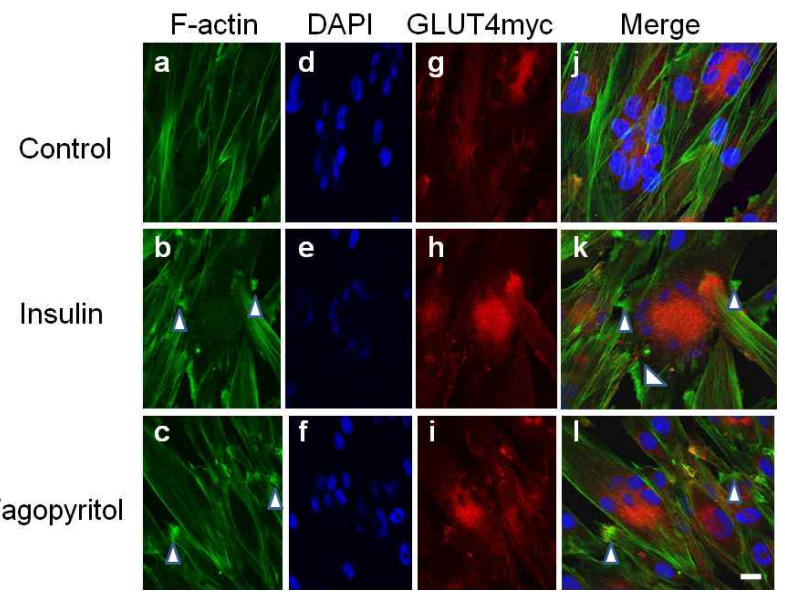

Fig. 3. Fagopyritol treatment induces GLUT4 translocation and $\mathrm{F}$ actin remodeling in L6-GLUT4myc myotubes. Serumdeprived L6-GLUT4myc myotubes were treated with 300 $\mathrm{nM}$ insulin or $1 \mathrm{mM}$ fagopyritol for $10 \mathrm{~min}$ at $37^{\circ} \mathrm{C}$. Afterward, the cells were fixed and double-stained for actin (green, rhodamine-phalloidin) and GLUT4myc (red, anti-myc antibody followed by Cy5-conjugated secondary antibody) as described in Methods. The multiple myonuclei were identified by DAPI staining (blue; $d$, e, and $\mathrm{f}$ ). White triangles indicate the $\mathrm{F}$ actin aggregates (b, c, k, and l). Scale bar, $10 \mu \mathrm{m}$. The images are representative of three experiments.

4. Cid, M. B., Alfonso, F. and Martín-Lomas, M. 2004. Synthesis of fagopyritols A1 and B1 from D-chiro-inositol. Carbohydr Res 339, 2303-2307.

5. Antonescu, C. N., Randhawa, V. K. and Klip, A. 2008. Dissecting GLUT4 traffic components in L6 myocytes by fluorescence-based, single-cell assays. Methods Mol Biol 457, 367-378.

6. Emoto, M., Langille, S. E. and Czech, M. P. 2001. A role for kinesin in insulin-stimulated GLUT4 glucose transporter translocation in 3T3-L1 adipocytes. J Biol Chem 276, 1067710682.

7. Fabjan, N., Rode, J., Kosir, I. J., Wang, Z., Zhang, Z. and Kreft, I. 2003. Tartary buckwheat (Fagopyrum tataricum Gaertn.) as a source of dietary rutin and quercitrin. J Agric Food Chem 51, 6452-6455.

8. Horbowicz, M. and Obendorf, R. L. 2005. Fagopyritol accumulation and germination of buckwheat seeds matured at 15,22 , and $30^{\circ} \mathrm{C}$. Crop Sci 45, 1264-1270.

9. Ishikura, S., Bilan, P. J. and Klip, A. 2007. Rabs $8 \mathrm{~A}$ and 14 are targets of the insulin-regulated Rab-GAP AS160 regulating GLUT4 traffic in muscle cells. Biochem Biophys Res Commun 353, 1074-1079.

10. Jordan, S. D., Könner, A. C. and Brüning, J. C. 2010. Sensing the fuels: glucose and lipid signaling in the CNS controlling energy homeostasis. Cell Mol Life Sci 67, 3255-3273.

11. Kanzaki, M., Watson, R. T., Khan, A. H. and Pessin, J. E. 2001. Insulin stimulates actin comet tails on intracellular GLUT4-containing compartments in differentiated 3T3L1 
adipocytes. J Biol Chem 276, 49331-49336.

12. Karlsson, H. K. and Zierath, J. R. 2007. Insulin signaling and glucose transport in insulin resistant human skeletal muscle. Cell Biochem Biophys 48, 103-113.

13. Kawa, J. M., Taylor, C. G. and Przybylski, R. 2003. Buckwheat concentrate reduces serum glucose in streptozotocin-diabetic rats. J Agric Food Chem 51, 7287-7291.

14. Khayat, Z. A., Tong, P., Yaworsky, K., Bloch, R. J. and Klip, A. 2000. Insulin-induced actin filament remodeling colocalizes actin with phosphatidylinositol 3-kinase and GLUT4 in L6 myotubes. J Cell Sci 113, 279-290.

15. Kishi, K., Muromoto, N., Nakaya, Y., Miyata, I., Hagi, A., Hayashi, H. and Ebina, Y. 1998. Bradykinin directly triggers GLUT4 translocation via an insulin-independent pathway. Diabetes 47, 550-558.

16. Klip, A., Li, G. and Logan, W. J. 1984. Induction of sugar uptake response to insulin by serum depletion in fusing L6 myoblasts. Am J Physiol 247, 291-296.

17. Leto, D. and Saltiel, A. R. 2012. Regulation of glucose transport by insulin: traffic control of GLUT4. Nat Rev Mol Cell Biol 13, 383-396.

18. Omata, W., Shibata, H., Li, L., Takata, K. and Kojima, I. 2000. Actin filaments play a critical role in insulin-induced exocytotic recruitment but not in endocytosis of GLUT4 in isolated rat adipocytes. Biochem J 346, 321-328.

19. Ostlund, R. E. Jr., McGill, J. B., Herskowitz, I., Kipnis, D. M., Santiago, J. V. and Sherman, W. R. 1993. D-chiro-inositol metabolism in diabetes mellitus. Proc Natl Acad SCi USA 90, 9988-9992.

20. Patel, N., Rudich, A., Khayat, Z. A., Garg, R. and Klip, A. 2003. Intracellular segregation of phosphatidylinositol-3,4,5trisphosphate by insulin-dependent actin remodeling in L6 skeletal muscle cells. Mol Cell Biol 23, 4611-4626.

21. Patki, V., Buxton, J., Chawla, A., Lifshitz, L., Fogarty, K., Carrington, W., Tuft, R. and Corvera, S. 2001. Insulin action on GLUT4 traffic visualized in single 3T3-L1 adipicytes by using ultra-fast microscopy. Mol Biol Cell 12, 129-141.

22. Rowland, A. F., Fazakerley, D. J. and James, D. E. 2011. Mapping insulin/GLUT4 circuitry. Traffic 12, 672-681.

23. Sbrissa, D., Ikonomov, O. C., Strakova, J. and Shisheva, A. 2004. Role for a novel signaling intermediate, phosphatidylinositol 5-phosphate, in insulin-regulated f-actin stress fiber breakdown and GLUT4 translocation. Endocrinology 145, 4853-4865.

24. Song, H. Y., Nam, Y., Kim, S. M., Kwon, S. O., Yeo, K. M., Kim, B. N. and Suh, J. G. 2009. Fagopyritol promote glucose uptake in L6 muscle cells. Lab Anim Res 25, 335-339.
25. Steadman, K. J., Burgoon, M. S., Schuster, R. L., Lewis, B. A., Edwardson, S. E. and Obendorf, R. L. 2000. Fagopyritols, D-chiro-inositol, and other soluble carbohydrates in buckwheat seed milling fractions. J Agric Food Chem 48, 2842-2847.

26. Thong, F. S., Dugani, C. B. and Klip, A. 2005. Turning signals on and off: GLUT4 traffic in the insulin-signalling highway. Physiology (Bethesda) 20, 271-284.

27. Tong, P., Khayat, Z. A., Huang, C., Patel, N., Ueyama, A. and Klip, A. 2001. Insulin-induced cortical actin remodeling promotes GLUT4 insertion at muscle cell membrane ruffles. J Clin Invest 108, 371-381.

28. Tsakiridis, T., Vranic, M. and Klip, A. 1994. Disassembly of the actin network inhibits insulin-dependent stimulation of glucose of glucose transport and prevents recruitment of glucose transporters to the plasma membrane. $J$ Biol Chem 269, 29934-29942.

29. Ueyama, A., Yaworsky, K. L., Wang, Q., Ebina, Y. and Klip, A. 1999. GLUT-4myc ectopic expression in L6 myoblasts generates a GLUT-4-specific pool conferring insulin sensitivity. Am J Physiol 277, 572-578.

30. Wang, Q., Bilan, P. J., Tsakiridis, T., Hinek, A. and Klip, A. 1998. Actin filaments participate in the relocalizastion of phosphatidylinositol3-kinase to glucose transporter-containing compartments and in the stimulation of glucose uptake in 3T3-L1 adipocytes. Biochem J 331, 917-928.

31. Wang, Q., Khayat, Z., Kishi, K., Ebina, Y. and Klip, A. 1998. GLUT4 translocation by insulin intact muscle cells: detection by a fast and quantitative assay. FEBS Lett 427, 193-197.

32. Wang, Q., Somwar, R., Bilan, P.J., Liu, Z., Jin, J., Woodgett, J. R. and Klip, A. 1999. Protein kinase B/Akt participtes in GLUT4 translocation by insulin in L6 myoblasts. Mol Cell Biol 19, 4008-4018.

33. Whiting, L., Danaher, R. N., Ruggiero, K., Lee, C. C., Chaussade, C., Mulvey, T., Phillips, A. and Loomes, K. M. 2013. D-chiro-Inositol attenuates epinephrine-stimulated hepatic glucose output in the isolated perfused liver independently of insulin. Horm Metab Res 45, 394-397.

34. Yao, Y., Shan, F., Bian, J., Chen, F., Wang, M. and Ren, G. 2008. D-chiro-inositol-enriched tartary buckwheat bran extract lowers the blood glucose level in KK-Ay mice. J Agric Food Chem 56, 10027-10031.

35. Yap, A., Nishiumi, S., Yoshida, K. and Ashida, H. 2007. Rat L6 myotubes as an in vitro model system to study GLUT4-dependent glucose uptake stimulated by inositol derivatives. Cytotechnology 55, 103-108. 
초록 : 랫드 근육세포에서 fagopyritol이 액틴 필라멘트 구조와 포도당 수송체 4에 미치는 영향

남하진 $^{1} \cdot$ 황인구 $^{2} \cdot$ 정혜리 ${ }^{3} \cdot$ 권승해 $^{4} \cdot$ 박옥규 $^{4} \cdot$ 서준교 $^{1,{ }^{3}}{ }^{*}$

( ${ }^{1}$ 한림대학교 천연의약연구소, ${ }^{2}$ 서울 대학교 수의학과, ${ }^{3}$ 한림대학교 의학유전학교실, ${ }^{4}$ 한국기초과학지원연구 원 춘천센터)

인슐린은 근육세포 표면으로 포도당 수송체 4(glucose transporter 4, GLUT4)를 유도하여 혈액 속의 포도당을 세포 내로 유입시키도록 작용한다고 알려져 있다. Fagopyritol은 인슐린과 유사한 작용을 하는 것으로 알려져 있 으므로, 본 연구에서는 혈당강하 효과가 있다고 알려진 fagopyritol을 랫드의 근육세포주(L6GLUT4myc 세포)에 처리하여, 아직 명확하게 밝혀지지 않은 fagopyritol의 혈당강하 기전을 규명하고자 수행하였다. Fagopyritol의 혈 당강하 기전을 규명하기 위하여 근원세포(myoblast)와 근관세포(myotube)에 fagopyritol을 처리하여 액틴 필라멘 트의 구조와 GLUT4에 미치는 영향을 분석하였다. Fagopyritol을 myoblast에 처리하였을 때, GLUT4가 처리군에 서 대조군과 비교하여 유의 있게 원형질막 쪽으로 유도되는 것을 확인하였고, 액틴 필라멘트의 구조가 재조정 되면서 GLUT4의 이동을 돕는 것으로 생각된다. 또한 fagopyritol이 인슐린과 유사한 작용 경로를 가지는지 확인 하기 위하여, 인슐린 작용 경로에서 중요한 역할을 하는 것으로 알려진 phosphatidylinositol 3-kinase (PI3K)의 억제제인 LY294002를 fagopyritol과 함께 처리하였을 때 GLUT4가 원형질막 쪽으로 유도되지 않는 것을 확인하였 다. Fagopyritol을 myotube에 처리하였을 때, myoblast에 처리하였을 때와 유사한 결과를 나타내었다. 이러한 결 과를 종합하면 fagopyritol이 인슐린과 유사한 작용을 하여 액틴 필라멘트의 구조 변경과 GLUT4의 이동을 촉진 시키는 것으로 사료된다. 